DOI: https://doi.org/10.31073/mivg20180108-148

Available at: http://mivg.iwpim.com.ua/index.php/mivg/article/view/148

УДК 628.1

\title{
ПОРІВНЯННЯ ЕФЕКТИВНОСТІ ФІЛЬТРУВАЛЬНИХ ЗАВАНТАЖЕНЬ
}

\author{
Д.В. Чарнийํㅜㄹ. докт. техн. наук, Ю.А. Онанко ${ }^{2}$, аспірант, Л.О. Семенко ${ }^{3}$, канд. с.-г. наук \\ ${ }^{1}$ Інститут водних проблем і меліорації НААН, Киӥв, Україна; \\ https://orcid.org/0000-0002-4632-0558; e-mail: dmitriych10@gmail.com \\ ${ }^{2}$ Інститут водних проблем і меліорації НААН, Київ, Україна; \\ https://orcid.org/()(0)-(0)(02-7231-1188: e-mail: yaonanko1@gmail.com \\ ${ }^{3}$ Інститут водних проблем і меліорації НААН. Київ, Україна; \\ https://orcid.org/0000-0002-4586-3681; e-mail: d26.362.01iwpim.naan@gmail.com
}

Анотація. Проведено аналіз перспективних для використання в умовах сучасної України фільтрувальних завантажень. Представлено характеристики, переваги і недоліки цеолітового та пінополістирольного фільтрувальних завантажень. Описано механізми затримання колоїдів із суспензій (вихідна вода як колоїдна системана цеолітових та пінополістирольних фільтрах. Встановлено $\zeta-$ потенціали колойдів вихідної води. Приведено порівняння роботи иих фільтрувальних завантажень на поверхневих водах верхів'я р. Дністер. Головним лімітуючим фактором даної вихідної води с каламутність, відповідно порівнювався ефект зниження каламутності за допомогою цих фільтрувальних завантажень. Встановлено характеристики иих фільтрувальних завантажень: брудомісткість, період роботи між промивками, об 'єм промивної води. Визначені перспективні напрямки розробки схем і конструкиій фільтрів на базі цих фільтрувальних завантажень та напрями покращення адсорбуючих властивостей пінополістирольного фільтрувального завантаження.

Ключові слова: водоочистка, водопідготовка, каламутність, фільтр, иеоліт, пінополістирол, пісок.

Актуальність. Обстеження стану діючих очисних споруд (як водопровідних, так i каналізаційних) [1] дозволило об єктивно визначити характерні проблеми, що потребують термінового вирішення. Це обстеження виявило, що однією 3 найбільш поширених i нагальних потреб $є$ необхідність заміни фільтруючого завантаження та капітального ремонту, або реконструкції корпусних споруд, в тому числі фільтрів. Більшість цих споруд були побудовані в 60-70 ті роки XX сторіччя за типовими проектами, в яких у якості фільтрувального завантаження закладений кварцовий пісок Волгоградського родовища. Цей фільтрувальний матеріал зараз втратив свою актуальність для систем водопостачання України. На даний час ведеться пошук альтернативного фільтрувального завантаження.

Таке фільтрувальне завантаження повинно забезпечити покращення роботи фільтрів і бути економічно доступним. Таким вимогам, на даному етапі соціально-економічного розвитку України відповідають два матеріали: гранули спіненого пінополістиролу "харчових" марок та природній цеоліт кліноптилоліт Сокирницького родовища.

Опис. Перспективним природним фільтрувальним завантаженням $\epsilon$ цеоліт, а як альтернативний йому можливо розглядати синтетичний полімерний матеріал - спінені гранули пінополістиролу. У кожного фільтрувального завантаження є свої переваги і недоліки. Цеоліт має природні адсорбційні і іонообмінні властивості, але порівняно швидко стирається при промивках, інтенсивність яких становить $-15-17 \pi /\left(\mathrm{c}^{\cdot} \mathrm{M}^{2}\right)$. У той час пінополістирол $є$ інертним матеріалом і має слабку стираємість, а для його промивки потрібна

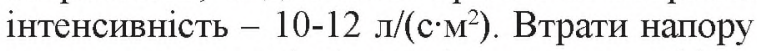
при використанні пінополістирольного фільтрувального завантаження на початку фільтроциклу складають - 3-4 см, а у цеоліту 25-40 см. Головні характеристики матеріалів наведено у таблиці.

Методика досліджень. Для порівняння ефективності роботи цих двох фільтрувальних матеріалів було проведено дослідне фільтрування природної поверхневої води. Досліджувався процес очищення поверхневих вод верхньої течії р. Дністер. Досліди проводили на базі водопровідних очисних споруд КП "Чернівціводоканал" м. Чернівці. Головним компонентом, що мав критичну вагу для цих вод, була каламутність. Дана величина визначалась за стандартною методикою ДСТУ ISO 7027:2003. 
1. Показники фільтрувальних матеріалів

\begin{tabular}{|c|c|c|c|c|c|}
\hline \multicolumn{2}{|c|}{ Фільтрувальний матеріал } & $\begin{array}{l}\text { Одиниці } \\
\text { виміру }\end{array}$ & $\begin{array}{l}\text { Квар- } \\
\text { цовий } \\
\text { пісок }\end{array}$ & Кліноптилоліт & Пінополістирол \\
\hline \multicolumn{2}{|c|}{ Пористість [2, 3$]$} & $\begin{array}{l}\text { Частки } \\
\text { одиниці }\end{array}$ & 0.410 & 0.510 & 0.450 \\
\hline \multicolumn{2}{|c|}{ Насипна щільність [2] } & $\kappa \Gamma / \mathrm{M}^{3}$ & 1700 & 1100 & 17 \\
\hline \multicolumn{2}{|c|}{ Об`ємна маса $[4]$} & $\Gamma / \mathrm{CM}^{3}$ & 1.63 & 1.43 & 0.17 \\
\hline \multicolumn{2}{|c|}{ Стираємість [2] } & $\%$ & 0.23 & 0.4 & 0.08 \\
\hline \multicolumn{2}{|c|}{ Інтенсивність промивки [5] } & $\pi /\left(c \cdot M^{2}\right)$ & 20 & $17-20$ & 10 \\
\hline \multicolumn{2}{|c|}{ Час промивки [5] } & $\mathrm{xB}$ & 17 & $10-15$ & $3-5$ \\
\hline \multicolumn{2}{|c|}{ Коефіцієнт форми зерен [2, 3] } & - & 1.17 & 2.20 & 1.30 \\
\hline \multicolumn{2}{|c|}{ Питома поверхня [3] } & $\mathrm{M}^{-1}$ & 4140 & 6470 & 4290 \\
\hline \multirow{3}{*}{$\begin{array}{c}\text { Відносні } \\
\text { Значення } \\
\text { показників [3] }\end{array}$} & Питома поверхня & - & 1.00 & 1.56 & 1.04 \\
\hline & $\begin{array}{c}\text { Гідродинамічний } \\
\text { вплив }\end{array}$ & - & 1.00 & 1.01 & 0.86 \\
\hline & Гідравлічний ухил & - & 1.00 & 1.27 & 0.82 \\
\hline \multirow{3}{*}{$\begin{array}{c}\text { Значення Rекр } \\
\text { [3] }\end{array}$} & $\delta=0,05$ & - & 1.43 & 1.90 & 1.87 \\
\hline & $\delta=0,10$ & - & 2.99 & 3.98 & 3.91 \\
\hline & $\delta=0,15$ & - & 4.77 & 6.35 & 6.23 \\
\hline \multicolumn{2}{|c|}{ ל- потенціал [1, 6-12] } & мB & -27 & -33 & 2 \\
\hline
\end{tabular}

Вода 3 вихідного каналу горизонтального відстійника надходила на фільтрувальні колонки. В якості фільтруючого завантаження порівнювалися пінополістирольні гранули і цеолітовий дрібияк. Фільтрація провадилася на швидкості 7 м/год - норматив для швидких фільтрів.

У процесі фільтрування визначався міжпромивний період фільтроциклу. Тобто період фільтрування до проскоку забруднень по каламутності - каламутність фільтрату більше $0,58 \mathrm{мг} /$ дм $^{3}$. У період промивки визначалась брудомісткість фільтра, тобто маса забруднень, затриманих у фільтруючому завантаженні за період фільтрування, що вимивається 3 промивною водою, і об’єм промивної води.

Для визначення таких електрокінетичних властивостей колоїдів як Ц- потенціал і гідродинамічний радіус використовували прилад Zetasizer Nano ZS виробництва Malvern Австрія. Дослідження проводили за методикою, що була розроблена виробником даного приладу.

Схема дослідної установки по проведенню дослідів 3 роботи фільтруючих завантажень наведена на рисунку 1 .

Вода 3 підвідного каналу горизонтального відстійника надходить у бак дегазатор - стабілізатор напору, з баку вода по шлангах надходить у фільтрувальні колонки $\Phi 1$ - 3 пінополістирольним завантаженням і
Ф2 - 3 цеолітовим дрібняком у якості фільтруючого завантаження. У Ф1 на фільтрацію вода надходить знизу, у Ф2 вода надходить згори. Швидкість фільтрування визначається об' ємним методом і виставляється за допомогою кранів на лініях скиду фільтрату. Промивка колонок провадиться у зворотному напрямі водою, накопиченою у баці дегазаторі - стабілізаторі напору. Під час промивки відбираються проби каламутності води, за якими визначається загальна концентрація каламутності промивної води. Спираючись на отримані дані були побудовані регресійні моделі змін концентрацій каламутності в процесі промивки модельної установки. Концентрацію забруднень у промивній воді за період промивки визначаємо як площу криволінійної трапеції, утвореної з ліній описаних рівняннями регресійних моделей і обмеженої часом промивки за допомогою інтегрування. До того ж функція зміни концентрацій обмежена у часі періодом промивки, отримана концентрація перемножувалась на кількість промивної води і таким чином отримували масу забруднень, вимитих промивною водою.

Результати дослідів i їx аналіз. Характеристики змін каламутності вихідної води і фільтрату за період фільтроциклу при швидкості фільтрування 7 м/год представлені на рисунку 2. 

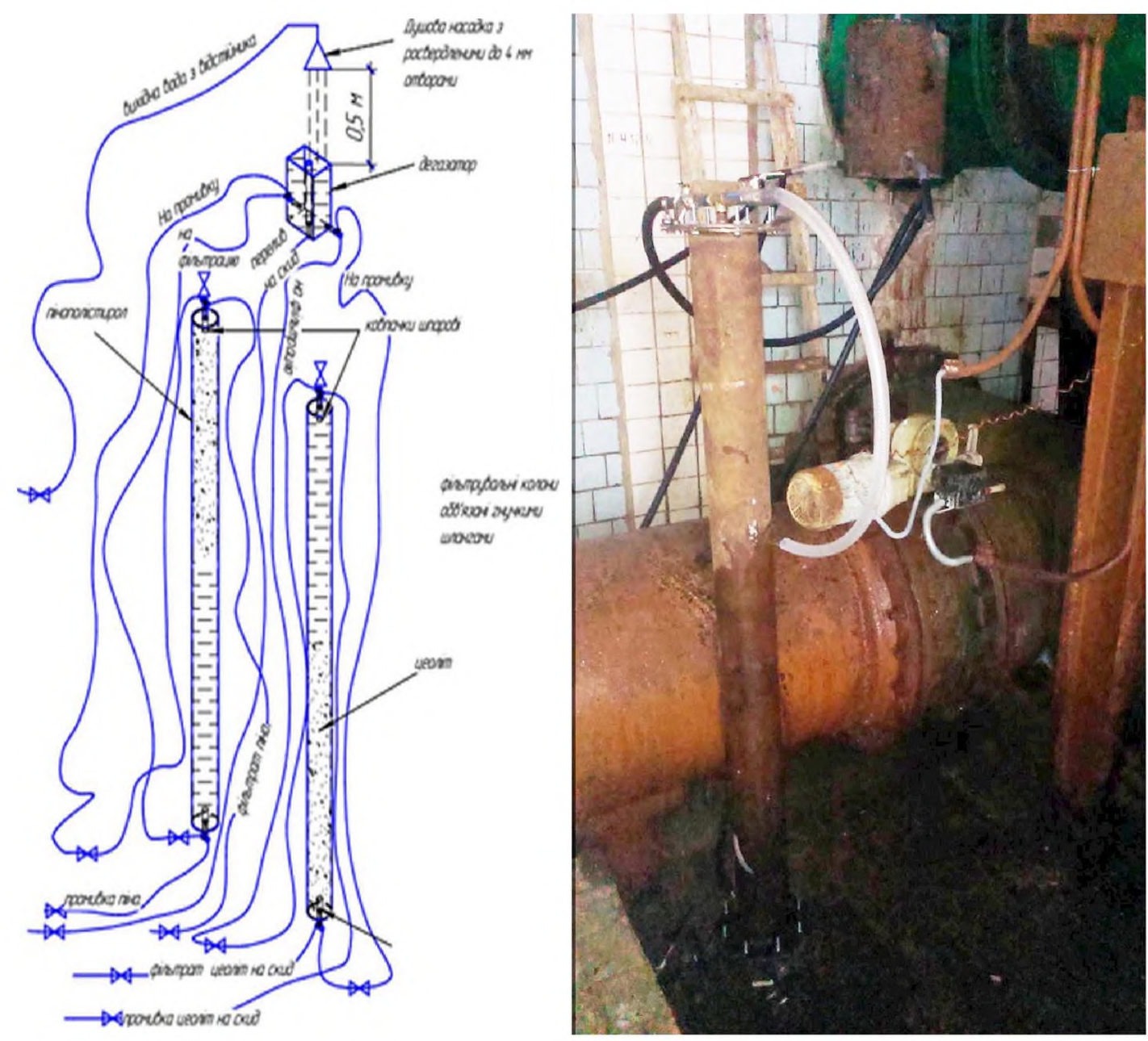

Рис. 1. Схема експериментальної установки

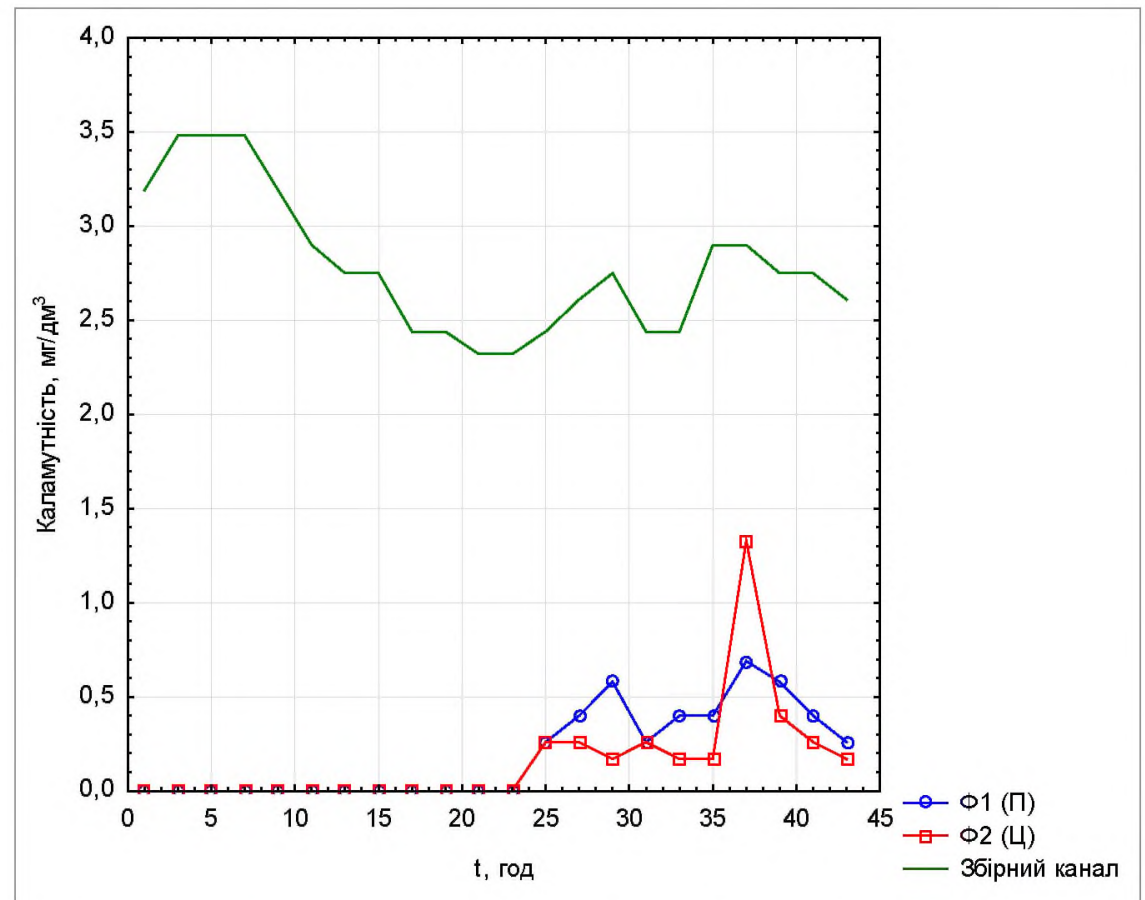

Рис. 2. Графіки змін каламутності вихідної води і фільтрату за період фільтроциклу при швидкості фільтрування 7 м/год 
Фільтрування води 3 вихідного каналу відстійників на пінополістирольному і цеолітовому фільтрувальному завантаженні провадилось при швидкості $\mathrm{V}_{\phi}=7$ м/год.

Визначення брудомісткості і тривалості фільтроциклу. Графіки промивки пінополістирольного та цеолітового фільтрів після фільтрування на швидкості 7 м/год протягом фільтроциклу представлені на рисунках 3 i 4 .

Криволінійні трапеції утворені за допомогою графіків рівнянь, що описують зміни каламутності у промивній воді під час промивки фільтрів, наведені на рисунках 3 і 4 . Для встановлення брудомісткості визначаємо

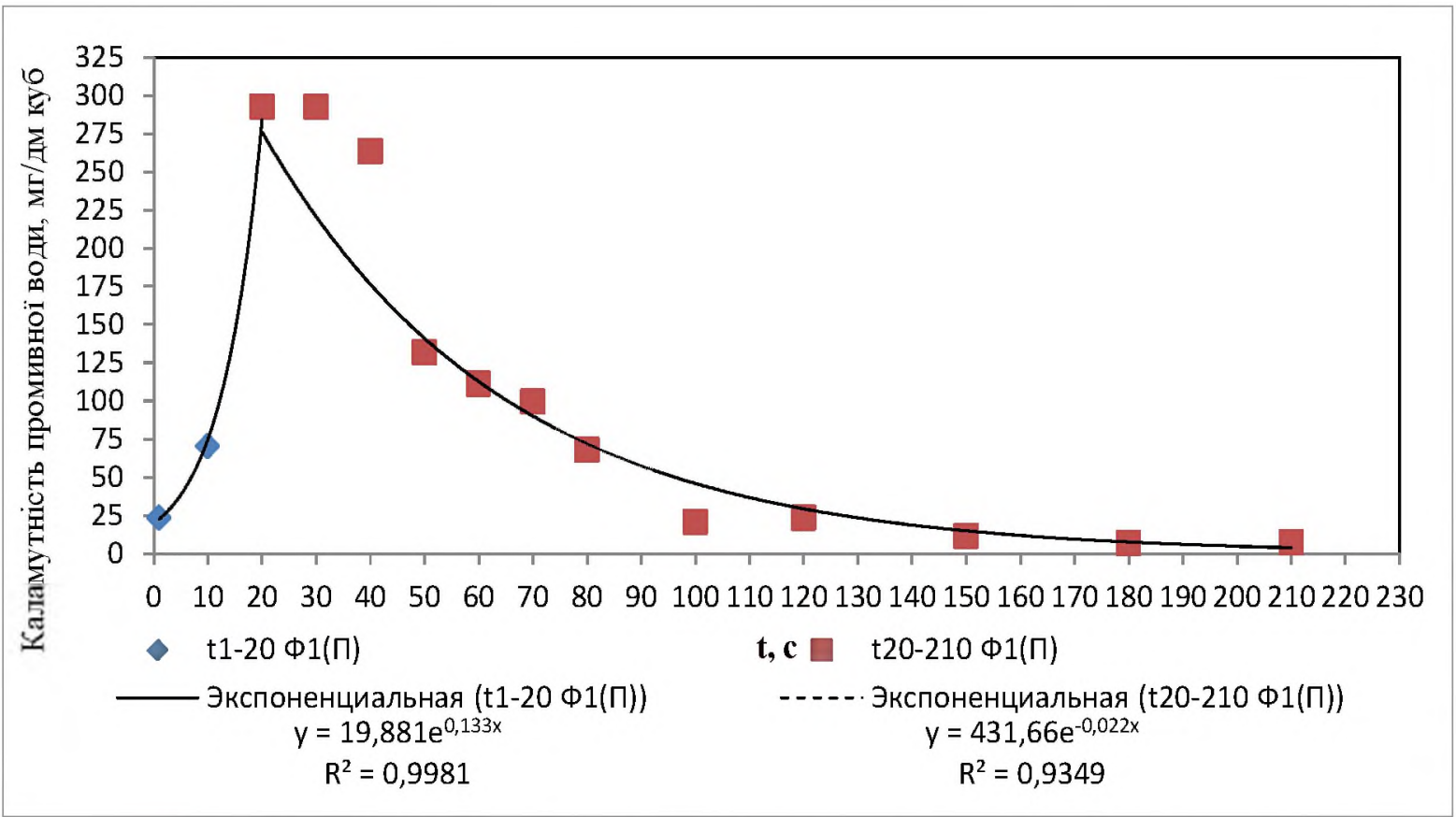

Рис. 3. Графік зміни каламутності промивної води за період фільтроциклу пінополістирольного фільтра при швидкості фільтрування 7 м/год

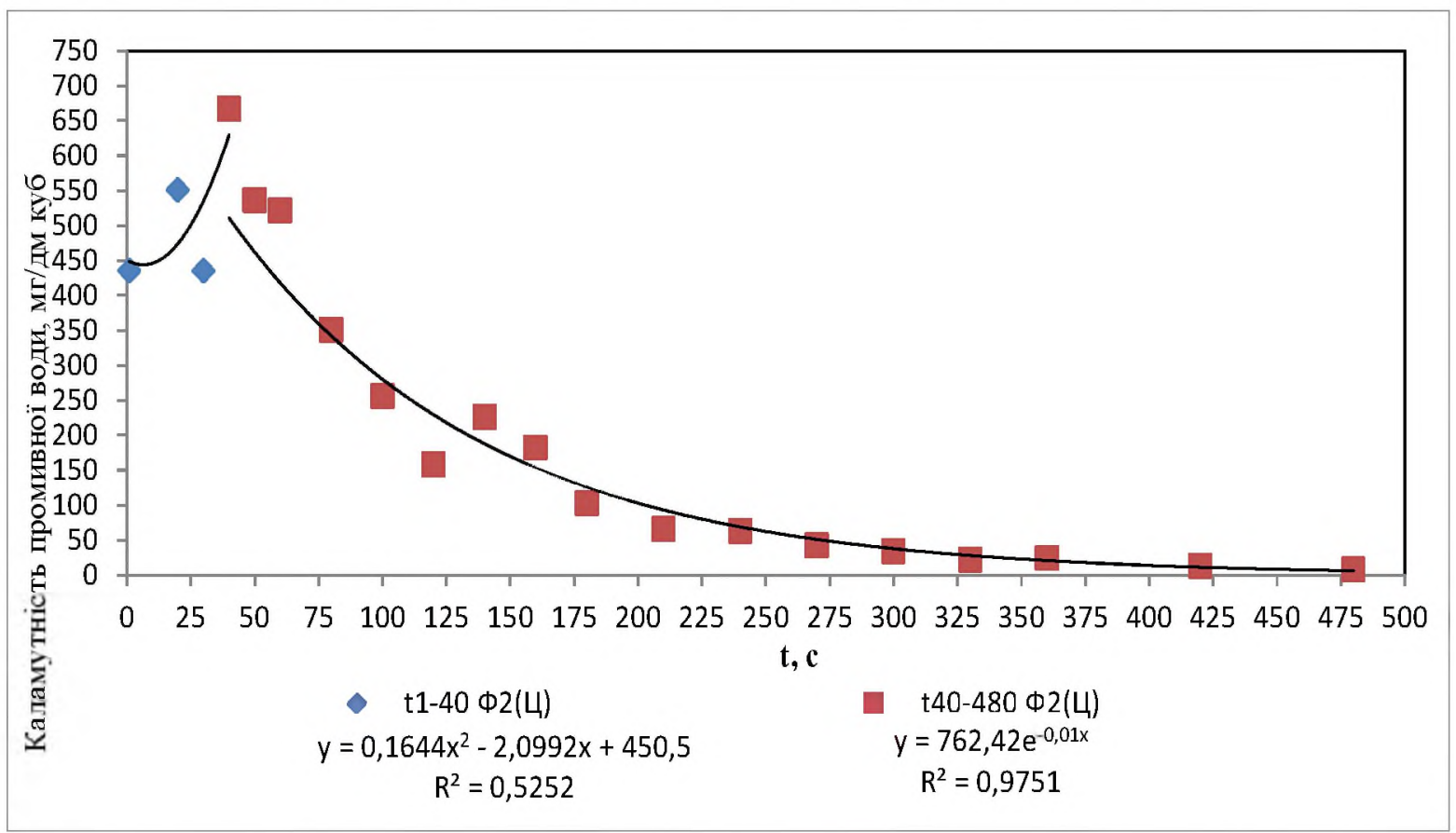

Рис. 4. Графік зміни каламутності промивної води за період фільтроциклу цеолітового фільтра при швидкості фільтрування 7 м/год 
площі криволінійних трапецій - концентрації промивної води з пінополістирольного фільтра:

$$
\begin{gathered}
\int_{1}^{20}\left(19,881 \cdot e^{0,133 t}\right) d t=1,966 \cdot 10^{3} \\
\int_{20}^{210}\left(431,66 \cdot e^{-0,022 t}\right) d t=2,244 \cdot 10^{4} .
\end{gathered}
$$

Звідки концентрація забруднень у промивній воді:

$$
C_{\text {npowat }}=\frac{\left(2,244 \cdot 10^{4}+1,966-10^{2}\right)}{1000}=24,406 \mathrm{z} / 0 \mathrm{~m}^{3} .
$$

Об єм промивної води 23,3 л.

Відповідно загальна кількість вимитих у процесі промивки забруднень становить: $24,406 * 23,3=568,66$ г.

Звідси загальна брудомісткість пінополістирольного фільтра становить:

$$
M_{\text {किण }}=\frac{(569.66)}{0.019} / 1000=31,59 \mathrm{keHa} 1 \mathrm{H}^{2} .
$$

Зміни каламутності промивної води цеолітового фільтра описуються рівняннями, наведеними на рисунку 4. Визначивши площі криволінійних трапецій встановлюємо загальну («концентрацію) каламутності в промивній воді:

$$
\begin{gathered}
\int_{1}^{40}\left(0,1644 \cdot t^{2}-2,0992 \cdot t+450,5\right) d t= \\
=1,94 \cdot 10^{4} . \\
\int_{40}^{480}\left(762,42 \cdot e^{-0,01 \cdot t}\right) d t=4,122 \cdot 10^{4} .
\end{gathered}
$$

Звідси концентрація забруднень у промивній воді:

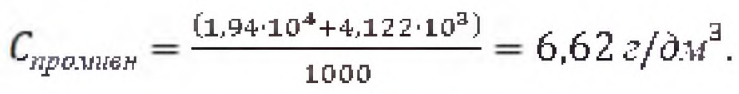

Об’єм промивної води 91 л.

Відповідно загальна кількість вимитих у процесі промивки забруднень становить: $6,62 * 91=602,42$ г.

Звідси загальна брудомісткість цеолітового фільтра становить:

$$
M_{\text {opd }}=\frac{(602,42)}{0.019} / 1000=33,468 \text { स2 }{ }^{2} 1 H^{2} \text {. }
$$

Схема затримання колоїдних суспензій цеолітового та пінополістирольного фільтрувальних завантажень. Для поверхневих природних вод, як складних колоїдних систем, характерна від'ємна зарядженість $\zeta$ - потенціалу колоїдів, що обумовлюють каламутність вихідної води. Це підтверджується нашими експериментальними дослідженнями поверхневих вод верхньої течії р. Дністер, за результатами яких величина $\zeta$ - потен- ціалу колоїдів у даній воді складає - 9,41 мВ. Пінополістирол $\epsilon$ інертним завантаженням 3 додатнім $\zeta-$ потенціалом, що складає +2 мВ $[1,7]$, тому адсорбція колоїдних частинок відбувається за рахунок різниці потенціалів. Найбільш наглядно це видно на прикладі затримання конгломератів ціанобактерій [1].

Схема роботи фільтрувального завантаження на базі цеолітів відрізняється від схеми затримання колоїдних часток пінополістиролом. Цеоліт має іонообмінні властивості і затримання катіонів на початку фільтроциклу відбувається за їх рахунок [13-15]. А потім він починає працювати як звичайний інертний матеріал, за рахунок різниці фаз і розвиненої питомої поверхні. Відповідно вплив $\zeta$ - потенціалу цеолітів при затримці колоїдів значно нижче, оскільки вони мають від' ємний ' - потенціал.

Перспективним напрямом розвитку фільтрувальних завантажень могла бути розробка такого завантаження, яке поєднувало б фільтрувальні характеристики цеоліту і пінополістиролу.

Висновки. Термін ефективної роботи пінополістирольного фільтрувального завантаження 25 годин, проти 35 годин у цеолітового фільтрувального завантаження.

Час промивки пінополістирольного фільтрувального завантаження 3,5 хв., проти 8 хв. у цеолітового фільтрувального завантаження.

Об'єм води, необхідний для промивки пінополістирольного фільтра, майже в чотири рази менший за об'єм необхідний для промивки цеолітового фільтра.

Запропоновано пояснення процесу затримання колоїдів на пінополістирольному і цеолітовому фільтрувальному завантаженні.

Запропоновано напрям по створенню нового фільтрувального завантаження.

Загальний висновок: цеолітове і пінополістирольне фільтрувальне завантаження досить близькі за своїми бар'єрними можливостями, в той же час сам механізм затримання, особливо на початковій стадії роботи, різний. Суттєво різняться гідравлічні характеристики цих фільтрувальних завантажень. Тобто при мінімізації будівельних витрат вигідніше використати завантаження на основі цеоліту, однак якщо враховувати експлуатаційні витрати, то безумовно вигіднішим стає завантаження зі спінених гранул пінополістиролу. Отже перспективними будуть дослідження в напряму створення фільтрувальних матеріалів на базі пінополістиролу 3 підвищеною питомою поверхнею і створенням конструкцій комбінованих фільтрів, які одночасно використовують обидва фільтрувальних завантаження. 


\section{Бібліографія}

1. Чарний Д. В. Розвиток теоретичних засад і удосконалення технологій очищення природних вод в системах сільськогосподарського водопостачання : дис. ... докт. техн. наук : 06.01.02 / Інститут водних проблем і меліорації НААН. Київ, 2017. 302 с.

2. Орлов В. О. Водоочисні фільтри із зернистою засипкою. Рівне : НУВГП, 2005. 163 с.

3. Кузнецов Л. К. Технология фильтрования в физико-химических процессах водоподготовки. Башкирский химический журнал. Уфа, 2009. Т. 16. № 2. С. 84-92.

4. Брек Д. Цеолитовые молекулярные сита. Москва : «Мир», 1976. 780 с.

5. ДБН В.2.5-74:2013. Водопостачання. Зовнішні мережі та споруди. Основні положення проектування. [Чинний від 2014-01-01]. Вид. офіц. Київ : Міністерство регіонального розвитку, будівництва та житлово-комунального господарства України, 2013. 172 с.

6. Голохваст К.С. Экотоксикология нано- и микрочастиц минералов // Известия Самарского научного центра Российской академии наук. Самара, 2011. Т. 13. № 1(5). С. 1256-1259.

7. Awet T. T. Effects of polystyrene nanoparticles on the microbiota and functional diversity of enzymes in soil. Environmental Sciences Europe. 2018. Vol. 30. № 1.

8. Wang X. Characterisation of electrokinetic properties of clinoptilolite before and after activation by sulphuric acid for treating csg water. Microporous and Mesoporous Materials. 2016. Vol. 220. P. 175-182.

9. Ozkan A. Investigation of coagulation and electrokinetic behaviors of clinoptilolite suspension with multivalent cations. Separation Science and Technology. 2017. Vol. 53. № 5. P. 823-832.

10. Kuzniatsova T. Zeta potential measurements of zeolite Y: application in homogeneous deposition of particle coatings. Microporous and Mesoporous Materials. 2007. Vol. 103. № 1-3. P. 102-107.

11.Jinkeun Kim. Characteristics of zeta potential distribution in silica particles. Bulletin of the Korean Chemical Society. 2005. Vol. 26. № 7. P. 1083-1089.

12.Antonio Alves Júnior J. The behavior of zeta potential of silica suspensions. New Journal of Glass and Ceramics. 2014. Vol. 04. № 02. P. 29-37.

13. Тарасевич Ю. І. Деманганація і знезалізнення артезіанської води в умовах промислових водозаборів м. Мукачеве (Закарпатська область) // Доповіді Національної академії наук України. Київ, 2014. № 10. С. 136-143.

14.Поляков В. Е. Очистка артезианской воды от ионов марганца и железа с использованием модифицированного клиноптилолита. Химия и технология воды. Київ, 1997. Т. 5. № 19. C. $493-505$.

15. Тарасевич Ю. И. Упрощенная модель обезжелезивания и деманганации воды на клиноптилолитовой загрузке фильтров // Химия и технология воды. Київ, 2013. Т. 35. № 2. С. 98-109.

\section{References}

1. Charny, D. V. (2017). Rozvytok teoretychnykh zasad i udoskonalennya tekhnolohiy ochyshchennya pryrodnykh vod v systemakh sil's "kohospodars "koho vodopostachannya [Development of theoretical principles and improvement of natural water treatment technology in agricultural water supply systems]. Doctor's thesis. Kyiv: Instytut vodnykh problem i melioratsiyi NAAN [in Ukrainian].

2. Orlov, V. O. (2005). Vodoochysni fil'try iz zernystoyu zasypkoyu. [Water-purifying filters with granular filler]. Rivne: NUVHP [in Ukrainian].

3. Kuznetsov, L. K. (2009). Tekhnologiya fil'trovaniya v fiziko-khimicheskikh protsessakh vodopodgotovki [Filtering technology in physico-chemical processes of water treatment]. Bashkirskiy khimicheskiy zhurnal - Bashkir Chemical Journal, 16(2), 84-92. Ufa: UGNTU [in Russian].

4. Brek, D. (1976). Tseolitovyye molekulyarnyye sita [Zeolitic molecular sieves]. Moskva: Izdatel'stvo «Mir» [in Russian].

5. Vodopostachannya. Zovnishni merezhi ta sporudy. Osnovni polozhennya proektuvannya [Water-supply. External networks and buildings fundamental designing statements]. (2013). DBN V.2.5-74:2013. From 01th January 2014. Kyiv: Ministerstvo rehional'noho rozvytku, budivnytstva ta zhytlovo-komunal'noho hospodarstva Ukrayiny [in Ukrainian|.

6. Golokhvast, K. S. (2011). Ekotoksikologiya nano- i mikrochastits mineralov [Ecotoxicology of nano- and microparticles of minerals]. Izvestiya Samarskogo nauchnogo tsentra Rossiyskoy akademii nauk - News of the Samara Scientific Center of the Russian Academy of Sciences, 13(1(5)), 1256-1259. Samara: SSCRAS [in Russian].

7. Awet, T. T., Kohl, Y., Meier, F., Straskraba, S., Grün, A.-L., Ruf, T., ... Emmerling, C. (2018). Effects of polystyrene nanoparticles on the microbiota and functional diversity of enzymes in soil. Environmental Sciences Europe, 30(1). https://doi.org/10.1186/s12302-018-0140-6 
8. Wang, X., \& Nguyen, A. V. (2016). Characterisation of electrokinetic properties of clinoptilolite before and after activation by sulphuric acid for treating CSG water. Microporous and Mesoporous Materials, 220, 175-182. https://doi.org/10.1016/j.micromeso.2015.09.003

9. Ozkan, A., Sener, A., \& Ucbeyiay, H. (2017). Investigation of coagulation and electrokinetic behaviors of clinoptilolite suspension with multivalent cations. Separation Science and Technology, 53(5), 823-832. https://doi.org/10.1080/01496395.2017.1380669

10.Kuzniatsova. T., Kim, Y., Shqau, K., Dutta, P. K., \& Verweij, H. (2007). Zeta potential measurements of zeolite $\mathrm{Y}$ : Application in homogeneous deposition of particle coatings. Microporous and Mesoporous Materials, 103(1-3), 102-107.

11. Jinkeun Kim, \& Desmond F. Lawler. (2005). Characteristics of Zeta Potential Distribution in Silica Particles. Bulletin of the Korean Chemical Society, 26(7), 1083-1089. https://doi.org/ $10.5012 /$ bkcs.2005.26.7.1083

12. Antonio Alves Júnior, J., \& Baptista Baldo, J. (2014). The Behavior of Zeta Potential of Silica Suspensions. New Journal of Glass and Ceramics, 04(02), 29-37. https://doi.org/10.4236/njgc.2014.42004

13. Tarasevych, Yu. I. (2009). Demanhanatsiya i znezaliznennya artezians'koyi vody v umovakh promyslovykh vodozaboriv $\mathrm{m}$. Mukacheve (Zakarpat•s"ka oblast") [Demaganization and disinfection of artesian water in the conditions of industrial water intakes in Mukachevo (Transcarpathian region)]. Dopovidi Natsional'noyi akademiyi nauk Ukrayiny - Statement of the National Academy of Sciences of Ukraine, 10, 136-143. Kyiv: NANU [in Ukrainian].

14.Poliakov, V.E. (1997). Ochistka artezianskoy vody ot ionov margantsai zheleza sispol'zovaniyem modifitsirovannogo klinoptilolita [Artesian water cleaning from the manganese and iron ions with the use of modified clinoptilolite]. Khimiya i tekhnologiya vody - Chemistry and technology of water, 5(19), 493-505. Kyiv: ICHHV NASU [in Russian].

15. Tarasevich, Yu. I. (2013). Uproshchennaya model' obezzhelezivaniya i demanganatsii vody na klinoptilolitovoy zagruzke fil'trov [Simplified model of water iron and manganese removal on the filters clinoptilolite load]. Khimiya i tekhnologiya vody - Chemistry and technology of water, 35(2), 98-109. Kyiv: ICHHV NASU [in Russian].

\section{Сравнение эффективности фильтрующих загрузок}

Аннотация. Проведен анализ перспективных для использования в условиях современной Украины фильтрующих загрузок. Представлены характеристики, преимуцества и недостатки цеолитовой и пенополистирольной фильтрующих загрузок. Описаны механизмы задержания коллоидов из суспензий (исходная вода как коллоидная система) на чеолитовых и пенополистирольных фильтрах. Определены $\zeta$ - потенциалы коллоидов исходной воды. Приведено сравнение работы этих фильтрующих загрузок на поверхностных водах верховья р. Днестр. Главным лимитируюиим фактором данной исходной воды является мутность, соответственно сравнивался эффект сниюения мутности с помощью этих фильтрующих загрузок. Установлены характеристики этих фильтрующих загрузок: грязеемкость, период работь между промывками, объем промывной воды. Определены перспективные направления разработки схем и конструкиий фильтров на базе этих фильтрующих загрузок и направления улучшения адсорбирующих свойств пенополистирольной фильтрующей загрузки.

Ключевые слова: водоочистка, водоподготовка, мутность, фильтр, цеолит, пенополистирол, песок.

\section{Comparison of the efficiency of some filter medias}

D.V. Charnyi, Yu.A. Onanko, L.O. Semenko Abstract. The analysis of prospective for Ukraine filter medias was carried out. The characteristics, advantages and disadvantages of zeolite and foam polystyrene filter medias are presented. The mechanisms of colloids retention from suspensions (source water as a colloidal system) in zeolite and foam polystyrene filters were described. The colloids potential of the source water was determined. The comparison of the operation of these filter medias when using the surface waters of the upper Dniester River is presented. The main limiting factor of this source water is turbidity, respectively, the reduction of water turbidity was compared when using these two filter medias. The following characteristics of these filter medias were determined: dirt intensity, operation period between flushing and a volume of flushing water. The perspective trends in designing filter schemes and structures based on these filter medias and the ways of improving the adsorbing properties of foam polystyrene filter media were established.

Key words: water purification, water preparation, turbidity, filter, zeolite, foam polystyrene, sand. 